ГАЛУЗЕВИЙ АСПЕКТ РОЗВИТКУ НАЦІОНАЛЬНОГО ГОСПОДАРСТВА

УДК 332.1

DOI: $10.25140 / 2411-5215-2020-1(21)-115-123$

Наталія Шадура-Никипорець, Оксана Мініна

\title{
УПРАВЛІННЯ ВІДХОДАМИ СІЛЬСЬКОГО ГОСПОДАРСТВА В ЧЕРНІГІВСЬКІЙ ОБЛАСТІ: ДОСЛІДЖЕННЯ ПОТОЧНОГО СТАНУ
}

\section{Наталия Шадура-Никипореи, Оксана Минина \\ УПРАВЛЕНИЕ ОТХОДАМИ СЕЛЬСКОГО ХОЗЯЙСТВА В ЧЕРНИГОВСКОЙ ОБЛАСТИ: ИССЛЕДОВАНИЕ ТЕКУЩЕГО СОСТОЯНИЯ}

\author{
Nataliia Shadura-Nykyporets, Oksana Minina \\ AGRICULTURAL WASTE MANAGEMENT IN THE CHERNIHIV REGION: \\ STUDY OF CURRENT SITUATION
}

\begin{abstract}
Стаття присвячена дослідженню існуючої в Чернігівській області системи управлінні відходами сільського господарства. Виявлено, щчо динаміка обсягів утворення та накопичення сільськогосподарських відходів у області носить зростаючий характер, щзо створює додаткове екологічне навантаження на територію. Встановлено, що значний вплив сфери сільськогосподарського виробництва на загальнообласні показники обсягів утворення відходів $з$ урахуванням волатильного характеру динаміки ї утворення та відмінної від національної траєкторії розвитку вимагає підвищеної уваги до діяльності виробників та контролю за їхнім поводженням з відходами з метою попередження загрозливого стану для довкілля.

Ключові слова: відходи; утилізачія; накопичення; відходи сільського господарства; екологія; система управління відходами; регіон.

Рис.: 6. Табл.: 2. Бібл.: 5.

Статья посвящена исследованию существующей в Черниговской области системы управлении отходами сельского хозяйства. Выявлено, что динамика объемов образования и накопления сельскохозяйственных отходов 8 области носит растущий характер, что создает дополнительную экологическую нагрузку на территорию. Установлено, что значительное влияние сферы сельскохозяйственного производства на областные показатели объемов образования отходов с учетом волатильного характера динамики их образования и отличающейся от национальной траекторией развития требует повышенного внимания к деятельности производителей и контроля за их обращением с отходами с иелью предупреждения угрожающего состояния для окружающей среды.

Ключевые слова: отходы; утилизачия; накопление; отходы сельского хозяйства; экология; система управления отходами; регион.

Рис.: 6. Табл.: 2. Библ.: 5.

The article is devoted to the research of the existing agricultural waste management system in Chernihiv region. It is revealed that the dynamics of the volume of generation and accumulation of agricultural waste in the region is of increasing nature, which creates additional environmental burden on the territory. It is established that the significant influence of agricultural production on the general indicators of the volume of waste generation, taking into account the volatile nature of the dynamics of their formation and different from the national development trajectory, requires increased attention to the activity of producers and control of their waste management in order to prevent a threatening state.
\end{abstract}

Keywords: waste, utilization, accumulation, agricultural waste, ecology, waste management system, region.

Fig.: 6. Table: 2. References: 5.

JEL Classification: R11; R50; Q01

Постановка проблеми. Прагнення України та ії регіонів відповідати європейським стандартам екологозбалансованого розвитку знайшли свою реалізацію в новій політиці управління відходами. Для іiі здійснення було ухвалено «Національну стратегію управління відходами в Україні до 2030 року», яка зорієнтована на вирішення критичної ситуації, що склалася з утворенням, накопиченням, зберіганням, переробленням, утилізацією та захороненням відходів і характеризується подальшим розвитком екологічних загроз [4; 5]. Для якісного виконання вимог Національної стратегії кожна область України повинна враховувати не лише їі загальні положення, а і власні регіональні особливості.

Аналіз останніх досліджень і публікацій. Питання формування, переробки, утилізації та поводження з відходами досліджували такі науковці, як О. Амосов, В. Голян, Б. Данилишин, Ж. Дерій, Н. Душечкіна, I. Замула, Ю. Маковецька, Л. Мельник, В. Міщенко, Р. Навроцький, І. Островський, І. Самойлова, В. Хільчевський та ін.

(C) Шадура-Никипорець Н. Т., Мініна О. В., 2020 
ГАЛУЗЕВИЙ АСПЕКТ РОЗВИТКУ НАЦІОНАЛЬНОГО ГОСПОДАРСТВА

Виділення недосліджених частин загальної проблеми. Специфіка господарської системи Чернігівської області вимагає деталізованого дослідження відходів сільського господарства як його ключової сфери. Оцінка поточного стану та виявлення тенденцій, що існують у сфері утворення і поводження з цієї категорією відходів, є пріоритетним завданням для забезпечення сталості розвитку регіону.

Мета статті. Метою цієї статті є дослідження існуючої в Чернігівському регіоні системи управління відходами сільського господарства.

Виклад основного матеріалу. Господарська система Чернігівської області за своєю спеціалізацією може вважатись агропереробною: у структурі валової доданої вартості Чернігівської області в 2017 р. найбільші частки мали сільське, лісове та рибне господарство - 28,21\% і промисловість - 20,54 \%, причому характерною тенденцією останніх років є зростання частки сільського господарства - $321,7 \%$ у 2013 р. до 28,2 \% у 2017 р [1]. Валова додана вартість сільського господарства регіону становить 4,5 \% ВДВ сільського господарства України (9 позиція в країні).

Як домінуюча в регіоні галузь, сільське господарство забезпечує роботою 25 \% всіх зайнятих працівників. Для розвитку галузі в області є об'єктивні передумови - значний потенціал сільськогосподарських угідь, загальна площа яких становить 2067,6 тис. га, або 64,8 \% земельного фонду [1]. За площею сільськогосподарських угідь, що становить 5 \% від загальної площі аналогічних угідь у країні, область посідає шосту позицію 3-поміж інших регіонів [3].

Основна спеціалізація галузі рослинництва регіону - вирощування зернових та технічних культур, тваринництва - молочно-м'ясне скотарство та виробництво свинини. У загальнодержавному виробництві продукції рослинництва область посідає 2-е місце по кукурудзі, 3-є - в зерновому господарстві, 5-е - по картоплі, 9-е - у виробництві сої, 13-є - цукрових буряків, 12-е - по соняшнику, 22-е - 3 вирощування овочів та 23-є місце по плодово-ягідних культурах. У загальнодержавному виробництві продукції тваринництва область посідає 23-є місце у виробництві м'яса (у забійній масі), 4-е - у виробництві молока, 20-е - у виробництві яєць та 19-е - вовни. Питома вага області у виробництві основних видів сільськогосподарської продукції в Україні у 2018 році становила: зернових культур - 7,0 \%, картоплі - 6,3\%, олійних $-4,3 \%$, овочів $-2,0 \%$, цукрових буряків - 1,8\%, у виробництві тваринницької продукції: молока $-5,3 \%$, яєць - 1,9\%, м'яса - 1,5\% [1;3].

Враховуючи аграрну спеціалізацію Чернігівської області, особливої уваги заслуговують відходи, згенеровані у цій сфері. Зважаючи на існуючі системи статистичного обліку, подібна інформація відображається за двома різними класифікаторами: при групуванні відходів за небезпечними складниками як «Відходи сільськогосподарського виробництва (за винятком пестицидів та отрутохімікатів, які прийшли у непридатність або заборонені для використання)» (код групи 1009), а при групуванні відходів за Класифікатором видів економічної діяльності (ДК 005-96) як відходи виробництва продукції сільського господарства. Дані, наведені в розрізі цих класифікацій, не збігаються, оскільки охоплюють різні одиниці дослідження. Тому проведемо аналіз, спираючись на дані обох класифікаторів.

Динаміка обсягів утворення відходів за видом економічної діяльності «Сільське господарство» у Чернігівській області (рис. 1) вказує наявну тенденцію до їх збільшення (виняток становить лише 2018 р.) - у 2018 р. річний обсяг формування відходів зріс на 28,4 \% порівняно з 2014 р. Тенденцію до зростання виявляє і зміна наявних у тимчасовому зберіганні у виробників відходів наприкінці року. Так, у 2018 р. показник досяг значення 66274,5 т, що становить $68,8 \%$ від утворених за рік та перевищує рівень 2014 р. на $439 \%$ [1; 2]. 
ГАЛУЗЕВИЙ АСПЕКТ РОЗВИТКУ НАЦІОНАЛЬНОГО ГОСПОДАРСТВА

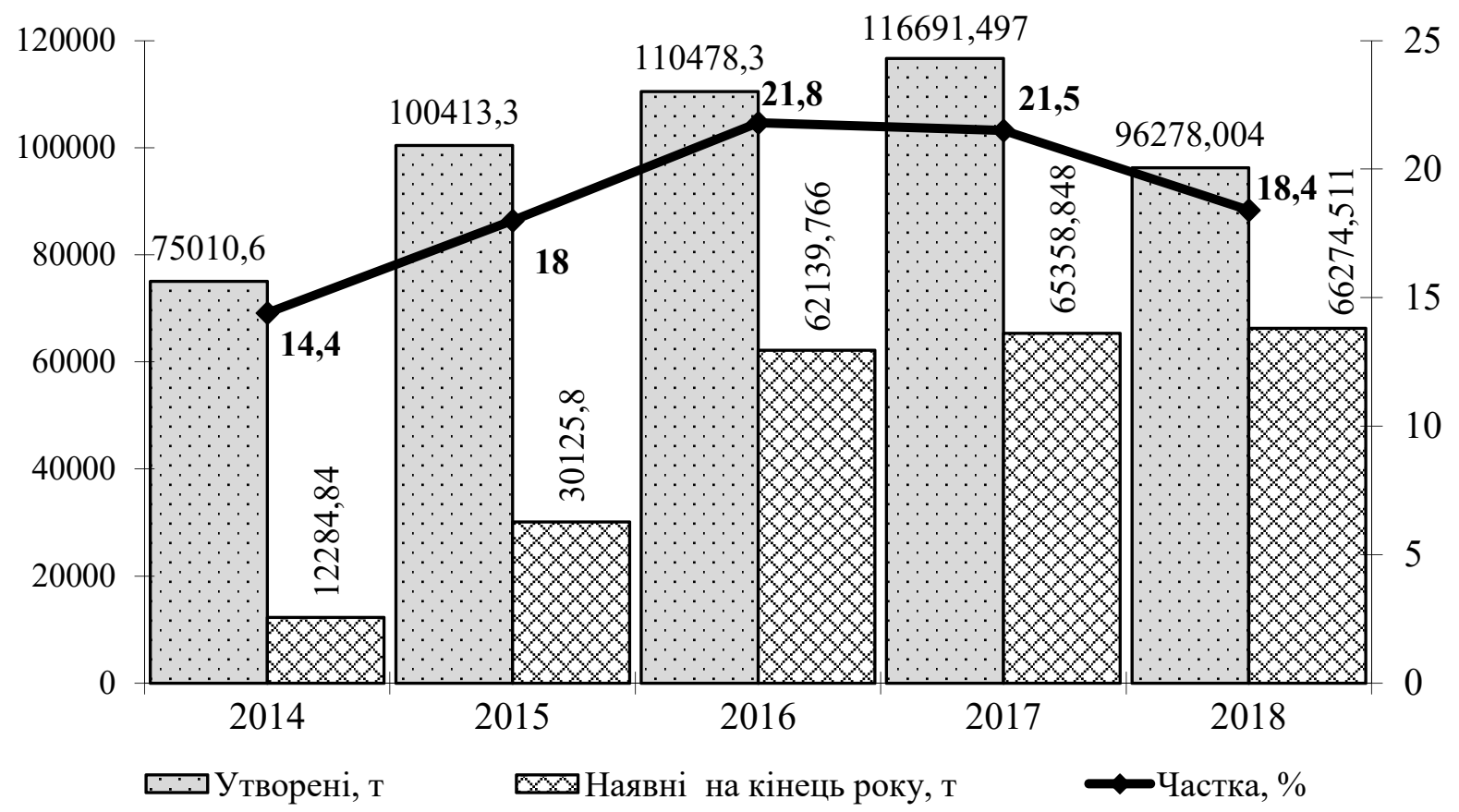

Рис. 1. Динаміка обсягів утворення та наявності у тимчасовому зберіганні відходів за видом економічної діяльності «Сільське господарство», 2018 р.

Джерело: [1].

Обсяги формування відходів цього виду економічної діяльності в Чернігівській області вносять вагомий внесок у загальне утворення відходів. Так, за даними 2018 р. у сукупному обсязі утворених за період відходів на сільське господарство приходиться $13,42 \%$, а у загальних відходах від економічної діяльності сягає 18,4 \% (рис. 2, табл. 1), що вимагає підвищеної уваги до діяльності суб'єктів сільськогосподарської сфери.

Доречно відзначити, що за винятком 2018 р., значна частка утворених відходів піддавалася утилізації (табл. 1).

Таблиця 1

Утворення та поводження з відходами за видом економічної діяльності «сільське господарство» у Чернігівській області, $m$

\begin{tabular}{|l|c|c|c|c|c|}
\hline \multirow{2}{*}{\multicolumn{1}{|c|}{ Показник }} & \multicolumn{5}{c|}{ Рік } \\
\cline { 2 - 6 } & 2014 & 2015 & 2016 & 2017 & 2018 \\
\hline Утворено & 75010,6 & 100413,3 & 110478,3 & 116691,497 & 96278,004 \\
\hline Спалено & $\ldots$ & $\ldots$ & 47,439 & 1097,209 & 1063,031 \\
\hline Утилізовано & 77462,53 & 97955,89 & 72487,259 & 102358,1 & - \\
\hline Передано на сторону & $\ldots$ & $\ldots$ & 5673,378 & 11068,427 & 8778,138 \\
\hline Наявні на кінець року & 12284,84 & 30125,8 & 62139,766 & 65358,848 & 66274,511 \\
\hline Накопичені на кінець року & 3439,816 & 3439,17 & 3484,47 & 3562,27 & 3659,71 \\
\hline $\begin{array}{l}\text { Частка в зальному обсязі } \\
\text { відходів від економічної } \\
\text { діяльності, \% }\end{array}$ & 14,4 & 18,0 & & & \\
\hline
\end{tabular}

Джерело: [1].

Утворення відходів, пов'язаних із функціонуванням економічного виду діяльності «Сільське господарство», пов'язано з діяльністю економічних суб'єктів, що працюють по всій території Чернігівської області, однак найбільші обсяги генерували у 2018 р. такі підприємства: ТОВ «Чернігівська індустріальна молочна компанія», Ріпкинський p-н, с. Великий зліїв та Чернігівський р-н, с. Шибиринівка (18 341,825 т), ТОВ «Менаавангард», м. Мена (17 171,0 т), Приватно-орендне сільськогосподарське підприємство 
ГАЛУЗЕВИЙ АСПЕКТ РОЗВИТКУ НАЦІОНАЛЬНОГО ГОСПОДАРСТВА

«Хлібороб», м. Ічня (5536,748 т), ТОВ «Елеватор агро», Прилуцький район, с. Івківці (5281,66 т), Приватно-орендне сільськогосподарське підприємство «Ічнянське», м. Ічня (4485,098 т.), Сільськогосподарський виробничий кооператив «Зоря», Сосницький район, с. Шаболтасівка (3177 т), Приватне сільськогосподарське підприємство «Степанич», Семенівський район, с. Залізний міст (3060 т) та ТОВ «Земля і воля», м. Бобровиця $(2316,69$ т) (рис. 2) [1].

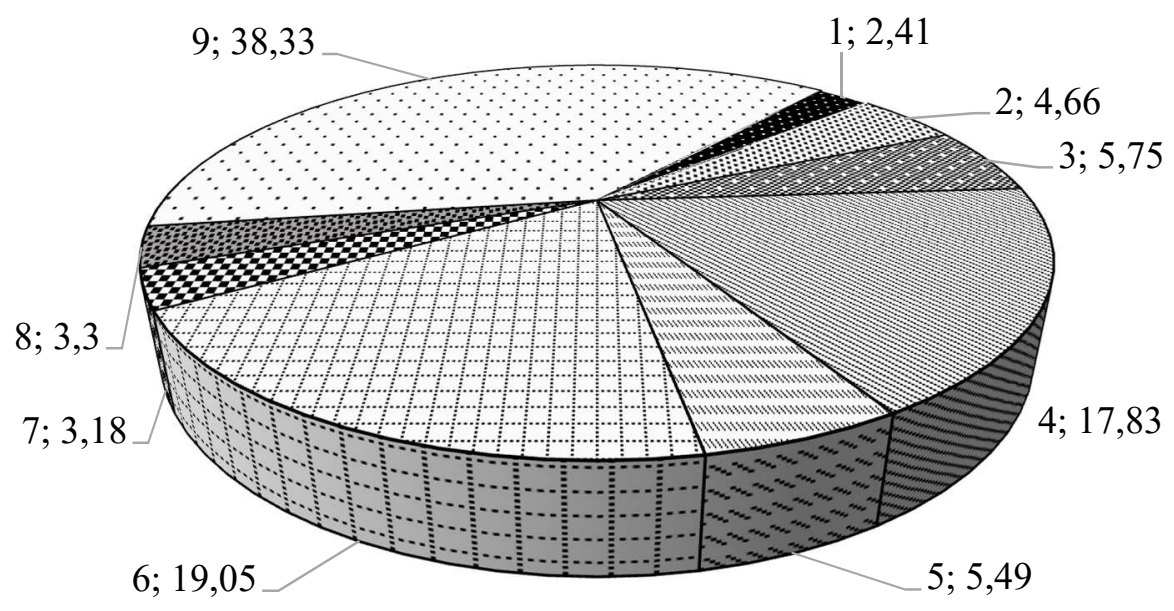

$1-$ ТОВ «Земля і воля»

2 - Приватно-орендне сільськогосподарське підприємство «Ічнянське»

3 - Приватно-орендне сільськогосподарське підприємство «Хлібороб»

4 - ТОВ «Мена-авангард»

5 - ТОВ «Елеватор агро»

6 - ТОВ «Чернігівська індустріальна молочна компанія»

7 - Приватне сільськогосподарське підприємство «Степанич»

8 - Сільськогосподарський виробничий кооператив «Зоря»

9 - інші

\section{Рис. 2. Внесок окремих підприємств в утворення відходів}

за видом економічної діяльності «Сільське господарство» у 2018 рочі, \%

Джерело: [1].

Варто відзначити, що два підприємства області (№ 4 та № 6) сукупно утворюють 36,88 \% відходів галузі, і ці відходи пов'язані з розведенням великої рогатої худоби молочних порід. Другим видом сільськогосподарської діяльності за обсягами утворення відходів у 2018 р. є вирощування зернових культур (крім рису), бобових культур і насіння олійних культур. Третю позицію посідає вирощування овочів і баштанних культур, коренеплодів і бульбоплодів.

Серед операцій поводження з відходами галузі у 2018 р. 1063,031 т (1,1% від утворених) було спалено, 8778,138 т (9,1 \% від утворених) передано на сторону, а решта накопичувалися [1]. За даними Головного управління статистики в Чернігівській області відповідно до звітів за формою № 1-відходи ні для підприємств, що утворюють відходи, ні підприємств, що здійснюють операції поводження з відходами. У 2018 р. дані про обсяги утилізації не відображено (табл. 1).

Підприємства-основні утворювачі відходів галузі відповідно і виступають суб'єктами, де частина цих відходів перебуває в тимчасовому триманні. Так, наприкінці 2018 р. наявні обсяги відходів у підприємств-виробників становили 65923,55 т (рис. 3), ще 350,961 т були наявні в переробників відходів. Слід звернути увагу, що 87,76 \% перебували в тимчасовому зберіганні одного підприємства - ТОВ «Менаавангард» [1]. 
ГАЛУЗЕВИЙ АСПЕКТ РОЗВИТКУ НАЦІОНАЛЬНОГО ГОСПОДАРСТВА

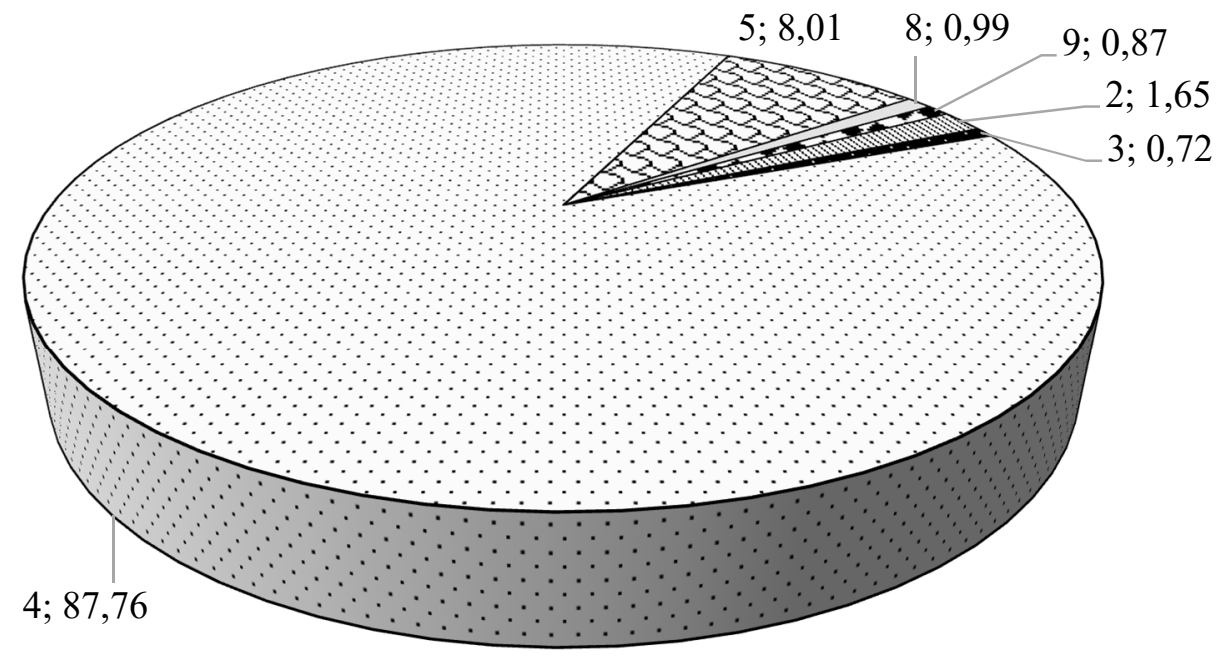

$1-$ ТОВ «Земля і воля»

2 - Приватно-орендне сільськогосподарське підприємство «Ічнянське»

3 - Приватно-орендне сільськогосподарське підприємство «Хлібороб»

4 - ТОВ «Мена-авангард»

5 - ТОВ «Елеватор агро»

6 - ТОВ «Чернігівська індустріальна молочна компанія»

7 - Приватне сільськогосподарське підприємство «Степанич»

8 - Сільськогосподарський виробничий кооператив «Зоря»

9 - інші

Рис. 3. Внесок окремих підприємств в обсяги наявних наприкіниі року відходів за видом економічної діяльності «Сільське господарство» у 2018 p.

Джерело: [1].

За інформацією Головного управління статистики в Чернігівській області у 2018 р. накопичення відходів здійснював лише один суб'єкт серед підприємств, що здійснюють операції поводження з відходами - Управління житлово-комунального господарства Чернігівської міської ради, де наприкінці року було зосереджено 3659,71 т відходів цього виду діяльності (табл. 1).

Подальше дослідження проведемо, спираючись на дані, наведені відповідно до групування відходів за небезпечними складниками. Так, група «Відходи сільськогосподарського виробництва (за винятком пестицидів та отрутохімікатів, які прийшли у непридатність або заборонені для використання)» (код групи 1009) містить ширший перелік відходів, ніж за попередньо розглянутою класифікацією, оскільки включає відходи сільськогосподарського характеру, що утворюються в інших видах економічної діяльності (наприклад, харчова промисловість тощо).

Перевагою такого підходу є можливість порівняння характеристик Чернігівської області з національними показниками.

Динаміка обсягів утворення відходів сільськогосподарського виробництва в Чернігівській області (рис. 4) вказує, що до 2016 р. відбувалося їх швидке прирощення, однак три останні роки поспіль сформувалася тенденція до такого ж стрімкого їх падіння, у підсумку обсяги 2018 р. перевищують рівень 2014 р. у 1,45 раза. При цьому за останні п'ять років обсяги відходів, що станом на кінець року перебувають у тимчасовому перебуванні у виробників, усталено зростають (у 2018 р. порівняно з 2014 р. показник зріс у 5,9 раза) [1]. Обсяги накопичених у спеціально відведених місцях відходів суттєвих змін не зазнали. 
ГАЛУЗЕВИЙ АСПЕКТ РОЗВИТКУ НАЦІОНАЛЬНОГО ГОСПОДАРСТВА

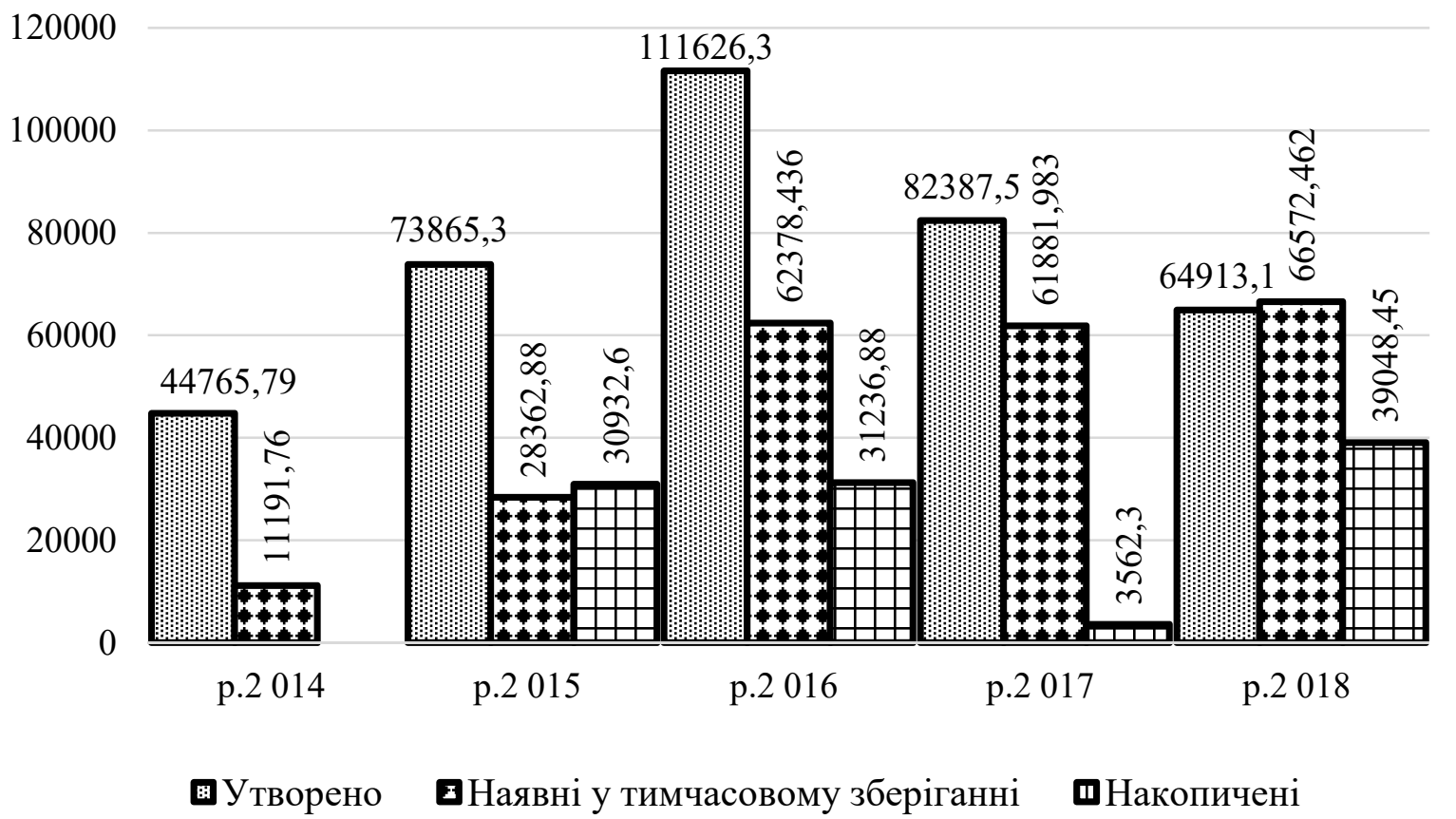

Рис. 4. Динаміка утворення та накопичення відходів сільськогосподарського Джерело: [1]. виробництва в Чернігівській області, $m$

Динаміка обсягів утворення відходів сільськогосподарського виробництва принципово не відповідає національним тенденціям (рис. 5, табл. 2).

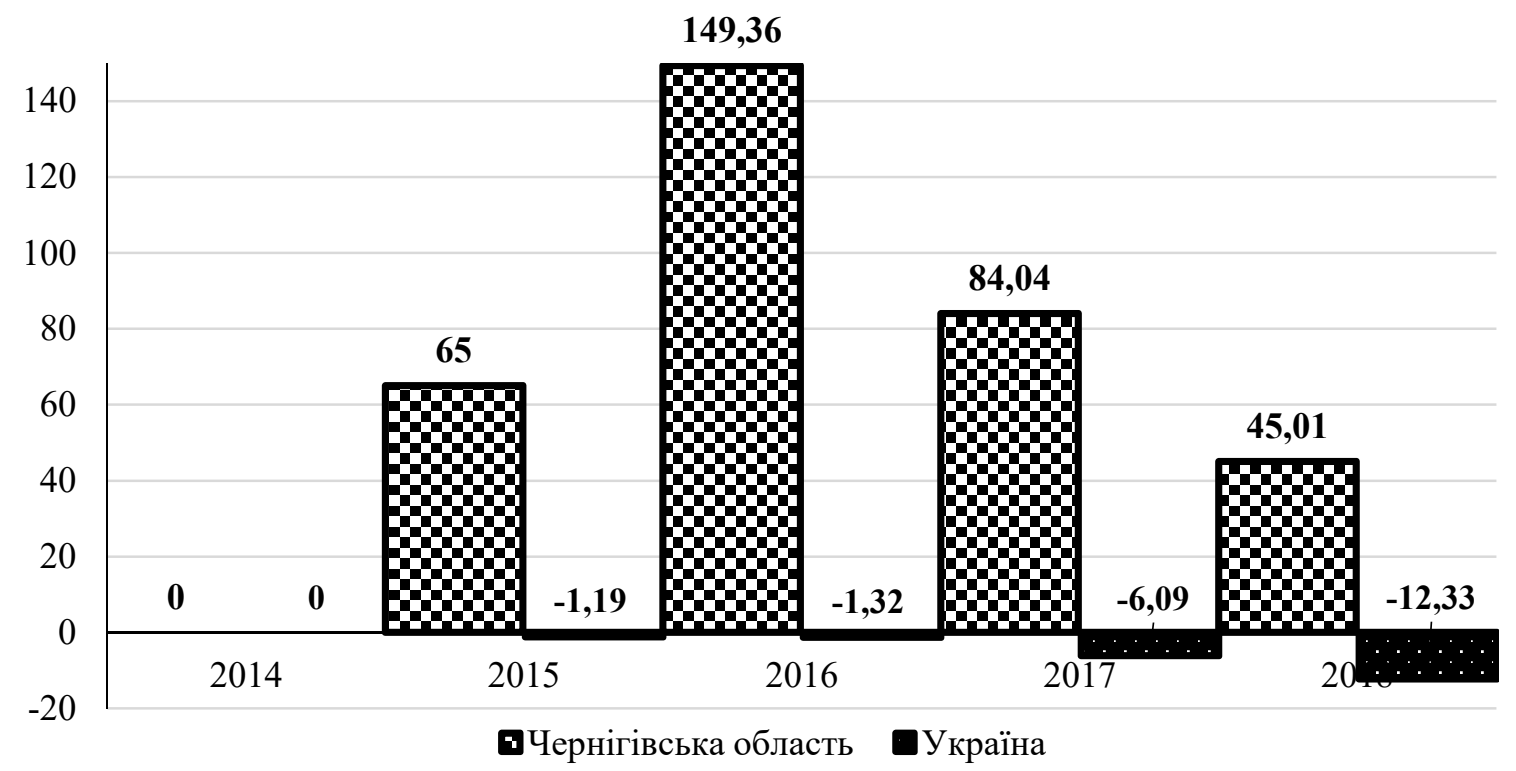

Рис. 5. Темпи приросту обсягів утворення відходів сільськогосподарського виробництва в Чернігівській області та Украӥні проти 2014 р., \%

Джерело: [1].

В Україні протягом останніх п'яти років сформувалася тенденція до скорочення обсягів утворення відходів (у порівнянні з 2014 р. у 2018 р. обсяги генерування відходів сільськогосподарського виробництва зменшилися на 12,33 \% [3]), що відображає лінійну зміну і має усталений характер. 
ГАЛУЗЕВИЙ АСПЕКТ РОЗВИТКУ НАЦІОНАЛЬНОГО ГОСПОДАРСТВА

Таблиця 2

Характеристики утворення та поводження із сільськогосподарськими відходами

\begin{tabular}{|c|c|c|c|c|c|}
\hline \multirow{2}{*}{ Показник } & \multicolumn{5}{|c|}{ Рік } \\
\hline & 2014 & 2015 & 2016 & 2017 & 2018 \\
\hline \multicolumn{6}{|c|}{ Україна } \\
\hline Обсяг утворення відходів протягом року, т & 9448,9 & 9336,2 & 9323,9 & 8873,4 & 8283,6 \\
\hline $\begin{array}{l}\text { Темп приросту обсягів утворених відходів } \\
\text { відносно } 2014 \text { р., \% }\end{array}$ & 0,00 & $-1,19$ & $-1,32$ & $-6,09$ & $-12,33$ \\
\hline $\begin{array}{l}\text { Частка утилізованих відходів у обсязі } \\
\text { утворених, \% }\end{array}$ & - & 59,07 & 58,46 & 50,53 & 57,30 \\
\hline \multicolumn{6}{|c|}{ Чернігівська область } \\
\hline Обсяг утворення відходів протягом року, т & 44765,79 & 73865,3 & 111626,3 & 82387,5 & 64913,1 \\
\hline $\begin{array}{l}\text { Темп приросту обсягів утворених відходів } \\
\text { відносно } 2014 \text { р., \% }\end{array}$ & 0,00 & $+65,00$ & $+149,36$ & +84.04 & $+45,01$ \\
\hline $\begin{array}{l}\text { Частка області у національному обсязі } \\
\text { утворення відходів, \% }\end{array}$ & 0,47 & 0,79 & 1,20 & 0,93 & 0,78 \\
\hline Утилізовано, т & 47374,04 & 72424,44 & 72412,259 & 67115,49 & 51912,5 \\
\hline $\begin{array}{l}\text { Частка області у національному обсязі ути- } \\
\text { лізації відходів, \% }\end{array}$ & - & 1,31 & 1,33 & 1,50 & 1,40 \\
\hline $\begin{array}{l}\text { Частка утилізованих відходів у обсязі } \\
\text { утворених, \% }\end{array}$ & 105,83 & 98,05 & 64,87 & 81,46 & 79,97 \\
\hline Накопичені відходи на кінець року, т & & 30932,6 & 31236,88 & 3562,3 & 39048,45 \\
\hline Наявні в тимчасовому зберіганні, т & 11191,76 & 28362,88 & 62378,44 & 61881,98 & 66572,46 \\
\hline
\end{tabular}

Джерело: [1;3].

Для Чернігівської області характерні принципово інші вияви зміни - на фоні національного скорочення в області проявляється стрімке хвилеподібне нарощення обсягів відходів. У підсумку таке розходження проявляється в тому, що наприкінці досліджуваного періоду обсяги утворення відходів сільськогосподарського виробництва в області зросли на 45,01 \% на фоні національного падіння на 12,33 \%. Це є свідченням нарощення масштабів сільськогосподарського виробництва в області темпами, що перевищують національні (індекси обсягу сільськогосподарського виробництва сільгосппідприємствами за весь досліджуваний період для області набувають вищого значення, ніж по Україні загалом: 2014 р. 107,7 \% проти 102,2 \%, 2015 р. 98,1 \% проти 95,2 \%, 2016 р. 111,5\% проти 110,0 \%, 2017 р. 105,3\% проти 96,8 \%, 2018 p. 115,6 \% проти $112,6 \%$ ) та вищого рівня відходомісткості в Чернігівській області (на це вказує перевищення темпів утворення відходів відносно темпів росту обсягу виробництва) [1; 3]. Збереження діючих моделей виробництва в сільському господарстві набуває характеру потенційної загрози.

Зовнішнім проявом проаналізованих змін є динаміка частки області за обсягами утворення відходів у національних показниках (табл. 2): якщо у 2014 р. показник становив лише 0,47\% то у 2018 р. він зріс до 0,78 \%, сягнувши пікового значення 2016 р. $(1,2 \%)$. Варто зазначити, що загалом частка області у формування відходів є відносно незначною (за обсягом реалізації сільськогосподарської продукції в країні на Чернігівську область приходиться понад 4\%) [1;3].

Динаміка обсягів утилізації відходів сільськогосподарського виробництва в Чернігівській області (рис. 6) та їі частки в Україні відображає позитивні зміни як за абсолютним, так і за відносним показником: обсяги утилізації зросли за останні п'ять років на $9,6 \%$, частка області за обсягами утилізації зросла з 1,31 до 1,4\%, а рівень утилізації відходів (співвідношення обсягу утилізованих відходів до утворених за період) для області є традиційно високим (у 2018 р. 79,97 \%) і традиційно перевищує національні показники (у 2018 р. для України рівень утилізації становить 57,3 \%). Утилізація в області зазвичай проводиться як обробка грунту, що справляє позитивний вплив на землеробство чи поліпшує екологічну ситуацію (R10) [1; 3]. 


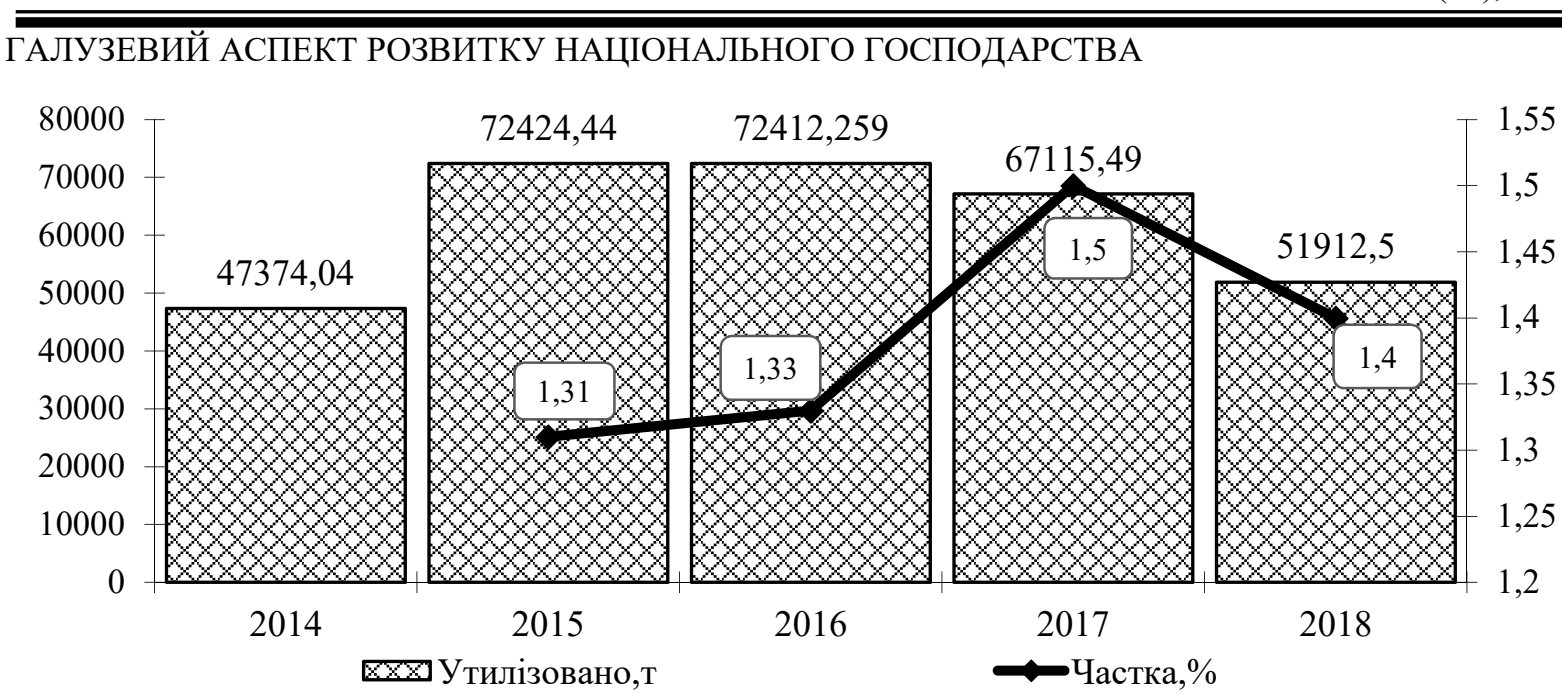

Рис. 6. Динаміка обсягів утилізації відходів сільськогосподарського виробнищтва в Чернігівській області (m) та ї̈ частки в Україні, \%

Джерело: [1; 3].

У 2018 р. сільськогосподарські відходи стали результатом діяльності 25 підприємств і становили 12,4 \% від загальної маси генерування відходів від економічної діяльності області.

У 2018 р. 246,7 т відходів отримано зі сторони, що на 58,5 \% більше рівня 2017 р. Отримані відходи надійшли від виробничої сфери (97,5 т) та перевізників і збирачів (149,2 т). Обробці (переробці) було піддано 51912,5 т відходів сільськогосподарського виробництва або 80 \% утворених за 2018 р., усі операції з утилізації проводили самі виробники відходів. Видалено у спеціально відведені місця 149,2 т, спалено 1004,5 т, передано на сторону 9468,237 т [1].

Протягом досліджуваного періоду операції поводження з відходами сільськогосподарського виробництва (зокрема зберігання відходів у місцях видалення відходів) заданими Головного управління статистики у Чернігівській області здійснювали три основні суб'єкти (відповідно до існуючої системи статистичного обліку ряд підприємств не подає форму звіту № 1-відходи), а саме Управління житлово-комунального господарства Чернігівської міської ради, приватне підприємство «ГРАНПЛАСТ» (включно до 2016 р.) та комунальне підприємство «АТП-2528» (з 2017 р.), де переважно відбувалося накопичення відходів у спеціально відведених місцях. Територіально всі основні суб'єкти інфраструктури поводження із сільськогосподарськими відходами розміщені в м. Чернігів, що створює додаткове екологічне навантаження на територію столиці області.

Висновки і пропозиції. Підсумовуючи проведений аналіз, варто відзначити певні наявні проблеми, що можуть сформувати потенційні загрози екологічному стану області. Невирішеною залишається ситуація з наявними на території Чернігівської області місцями накопичення заборонених і непридатних до використання хімічних засобів захисту рослин. Станом на початок 2019 р. наявні 284,3 т таких пестицидів у Бахмацькому, Борзнянському, Варвинському, Ічнянському, Носівському, Прилуцькому, Ріпкинському, Семенівському, Срібнянському, Сосницькому, Сновському, Чернігівському районах та м. Прилуки.

Значний вплив сфери сільськогосподарського виробництва на загальнообласні показники обсягів утворення відходів з урахуванням волатильного характеру динаміки їх утворення та відмінної від національної траєкторії розвитку вимагає підвищеної уваги до діяльності виробників та контролю за їхнім поводженням з відходами з метою попередження загрозливого стану для довкілля.

Хоч загальна ситуація з рівнем утилізації сільськогосподарських відходів у Чернігівській області є достатньо стабільною, однак використання виробниками для утилізації лише однієї форми (обробка грунту, що справляє позитивний вплив на землеробство чи поліпшує екологічну обстановку (R10)) вимагає їхнього розширення. 
ГАЛУЗЕВИЙ АСПЕКТ РОЗВИТКУ НАЦІОНАЛЬНОГО ГОСПОДАРСТВА

Відсутність повної достовірної інформації щодо утворення та поводження з сільськогосподарськими відходами у зв'язку з частковим охопленням власників відходів статистичним спостереженням ускладнює об'єктивний аналіз та розробку заходів 3 поліпшення управління цією сферою.

Концентрація накопичених відходів територіально зосереджена у м. Чернігів, що створює додаткове екологічне навантаження на територію столиці області.

\section{Список використаних джерел}

1. Головне управління статистики у Чернігівській області. URL: http://www.chernigivstat.gov.ua/ books/silgosp.php.

2. Доповідь про стан навколишнього природного середовища в Чернігівській області у 2018 році. URL: http://eco.cg.gov.ua.

3. Офіційний сайт Державної служби статистики України. URL: http://www.ukrstat.gov.ua.

4. Про схвалення «Національної стратегії з управління відходами в Україні до 2030 року : Розпорядження Кабінету Міністрів України № 820-p від 08 листопада 2017 p. URL: https://zakon.rada.gov.ua/laws/show/820-2017-\%D1\%80.

5. Derii Z. V., Zosymenko T. I. Environmental component of corporate social responsibility: International experience and Ukrainian realities. Actual Problems of Economics. 2016. Vol. 185, Issue 11. P. 278-290.

\section{References}

1. Holovne upravlinnia statystyky u Chernihivskii oblasti [Main Department of Statistics in Chernihiv region] (n.d.). Retrieved from http://www.chernigivstat.gov.ua/books/silgosp.php.

2. Dopovid pro stan navkolyshnoho pryrodnoho seredovyshcha v Chernihivskii oblasti u 2018 rotsi [Report on the state of the environment in the Chernihiv region in 2018]. Retrieved from http://eco.cg.gov.ua.

3. Ofitsiinyi sait Derzhavnoi sluzhby statystyky Ukrainy [Official site of the State Statistics Service of Ukraine]. Retrieved from http://www.ukrstat.gov.ua.

4. Pro skhvalennia «Natsionalnoi stratehii z upravlinnia vidkhodamy v Ukraini do 2030 roku [On approval of the "National Strategy for Waste Management in Ukraine until 2030]. № 820-r (of November 8, 2017). Retrieved from https://zakon.rada.gov.ua/laws/show/820-2017-\%D1\%80.

5. Derii, Z. V., Zosymenko, T. I. (2016). Environmental component of corporate social responsibility: International experience and Ukrainian realities. Actual Problems of Economics, 185 (11), 278-290.

Шадура-Никипорець Наталія Тимофіївна - кандидат економічних наук, доцент, доцент кафедри теорети-

чної та прикладної економіки, Чернігівський національний технологічний університет (вул. Шевченка, 95, м. Чернігів, 14035, Україна).

Шадура-Никипорец Наталия Тимофеевна - кандидат экономических наук, доцент, доцент кафедры теоретической и прикладной экономики, Черниговский национальный технологический университет (ул. Шевченко, 95, г. Чернигов, 14035, Украина).

Shadura-Nykyporets Nataliia - PhD in Economics, Associate Professor, Associate Professor of Department of theoretical and applied Economics, Chernihiv National University of Technology (95 Shevchenka Str., 14035 Chernihiv, Ukraine).

E-mail: nikiporetc@ukr.net

ORCID: http://orcid.org/0000-0001-7990-0105

Researcher ID: H-1176-2016

Мініна Оксана Валеріївна - кандидат економічних наук, доцент, доцент кафедри теоретичної та прикладної економіки, Чернігівський національний технологічний університет (вул. Шевченка, 95, м. Чернігів, 14035, Україна).

Минина Оксана Валериевна - кандидат экономических наук, доцент, доцент кафедры теоретической и прикладной экономики, Черниговский национальный технологический университет (ул. Шевченко, 95, г. Чернигов, 14035, Украина).

Minina Oksana - PhD in Economics, Associate Professor, Associate Professor of Department of theoretical and applied Economics, Chernihiv National University of Technology (95 Shevchenka Str., 14035 Chernihiv, Ukraine).

E-mail: minina.ok.v@gmail.com

ORCID: http://orcid.org/0000-0002-5919-1599

Researcher ID: H-1167-2016

Шадура-Никипорець Н., Мініна О. Управління відходами сільського господарства в Чернігівській області: дослідження поточного стану. Проблеми і перспективи економіки та управління. 2020. № 1 (21). С. 115-123. 